thickened so as to constitute a U-endodermis. Inside this is a simple pericycle, where some cells show a tangential division; the groups of leptome and hadrome border on this pericycle, as in other roots. But a root measuring about $72^{\text {ma }}$ in diameter shows that these tangential divisions of the pericycle do not produce any secondary parenchyma. There is, however, a secondary parenchyma present, but this is located in the bark, representing a secondary bark, of which the primary layers rest immediately upon the endodermis. The secondary meristem, from which these tissues have originated, has been formed in the innermost layers of the primary bark. When this secondary parenchyma developed in the bark, the pericycle commenced to show tangential divisions in various places, especially where it consisted of from seven to eight rows of radially arranged cells.

This increase of the pericycle causes a pressure from the interior to the exterior; thus the endodermis becomes ruptured in certain places, and a communication opens between the central cylinder and the cortical zone. The cells of the pericycle come to be, in this way, in contact with the secondary bark. These pericycle cells show, thereupon, a beginning sclerosis of their membranes.

The result of this investigation is that although the secondary formations in the root of Draccena have originated from the bark, the pericycle may, nevertheless, show a certain activity, so as to produce a pressure from the interior to the exterior, by which action the endodermis becomes ruptured. A communication is thus established between the two conducting systems, the primary and the secondary.

THEO. HOLM.

\title{
Vegetable ferments.
}

There is hardly any branch of physiology which claims our attention more than that including the ferments. In the animals, as well as in the plants, their action is so important that it is impossible to form any opinion of the act of nutrition unt less we keep a steady look at the ferments. Much has no: been done yet, but it is a very desirable work that has beet done by Professor J. R. Green, ${ }^{6}$ namely, "to give soml account of the various vegetable enzymes now known to ex-

${ }^{6}$ On vegetable ferments. Annals of Botany 7: 83-137. 1893 . 
ist; to review their general properties, mode of action, and composition." He has also cited the literature of the subject extensively, for which the original paper must be consulted.

I. CARBohydrate ENZYMES.

I. Diastase. Baranetzky found it in many plants, and it has been made the object for a special study by Kjeldahl, Brown and Morris, and others, especially in barley-seeds where it appears at an early stage of development and where it is found in the part of the endosperm adjoining the embryo, preparing the food for the latter out of the starch present in the grain. In leaves, its existence was known, and its function thought to be that of converting starch into sugar. Wortman, however, did not ascertain its existence, whence he concluded that the protoplasm had, itself, this function. Vines and St. Jentys gave afterwards new evidence of its presence and function. This so-called translocation-diastase will dissolve starch-grains without corrosion, has an optimum-temperature of $45^{\circ}-50^{\circ} \mathrm{C}$, and liquefies starch-paste slowly. Another form, viz., the diastase of secretion, was found by Brown and Morris, and Haberlandt; it is formed shortly after the beginning of the germination in the epithelium of the scutellum, dissolving starch-grains by corrosion. It liquefies starchpaste rapidly and has its optimum temperature at $50^{\circ}-55^{\circ} \mathrm{C}$. The final product of the transformation is apparently maltose, the intermediate members being unknown.

2. Inulase. In Dahlia, Helianthus tuberosus, and Inula Helenium, the reserve-material of the tubers is inuline, and a corresponding ferment, inulase, has been found.

3. Invertase. This ferment inverts cane-sugar into dextrose and levulose. It has been found in an extract of malt, in leaves and buds by Kossmann, in pollen-grains, in petals of Robinia Pseudacacia, in the embryo of germinating barley by Kjeldahl and O'Sullivan, and in several of the Saccharomyces, in Fusarum, and in Aspergillus niger.

4. Cyto-hydrolytic enzymes. These transform cellulose, Phore this is present as a reserve material, as in the seeds of zyme is present in the tissues in the hyphæ of Botrytis which was growing ley it has been found candidum. Also in germinating bar-

II. GLucos found by Brown and Morris.

I. Emulsin or ENZYMES.

lus, Cerasus or synaptase. In certain species of Amygda- 
forming prussic acid and sugar: $\mathrm{C}_{20} \mathrm{H}_{27} \mathrm{NO}_{1 \mathrm{I}}+2 \mathrm{H}_{2} \mathrm{O}=\mathrm{C}_{6} \mathrm{H}_{5} \mathrm{COH}$ $+\mathrm{HCN}+2\left(\mathrm{C}_{6} \mathrm{H}_{12} \mathrm{O}_{6}\right)$. Its place in the bitter almonds was studied by Johannsen and Guignard; the latter found it in special cells in the parenchyma of all parts of the plant; the greatest amount was, however, found in the seeds.

2. Rhamnase. In seeds of Rhamnus infectorius, it decomposes the glucoside xanthorhamnin into rhamnin and sugar.

3. Erythrozym.

III. Proteo-hydrolytic Enzymes. Ferments of this group decompose proteids.

1. Pepsin is the most notable of these. Its presence in the fluid excreted by Drosera, Nepenthes, Dionaea, Pinguicula, Sarracenia, etc. is well known, as well as the theories based upon these facts, and also the lately announced Russian experiments. ${ }^{7}$ A peptonizing ferment was also found by Krukenberg in Æthalium septicum.

2. Tryptic enzymes. In Carica Papaya one of these, the papain, has been observed; in the fruit of the pine-apple, Chittenden found another enzyme of this group. In the seeds of the vetch Gorup-Besanez found an enzyme, and also in the seeds of flax, hemp, and barley, while Green worked with the lupines. How these ferments work in the plants has not yet been satisfactorily investigated.

3. Rennet. In Galium verum, a substance was long since noticed which was able to coagulate milk. Afterwards, an enzyme was found in Pinguicula vulgaris by Linné and Darwin, in Withania coagulans (seeds) by Lea, in Datura Stramonium, Pisum sativum, Lupinus hirsutus, and Ricinus communis, by Green. We may add that rennet has also been isolated from bacteria by Conn. ${ }^{8}$

IV. Glyceride enzymes. Such are able to decompose oils or fats. Müntz was the first who paid attention to the splitting up of the oils in germinating seeds. In Ricinus communis an enzyme was found; it decomposes fats into fatty acids and glycerin. In many other seeds of this group similar enzymes have been noticed.

In many fungi and bacteria, enzymes are present. Five distinct enzymes were found by Vignal in the Bacillus mesentericus vulgatus: diastase, invertase, rennet, and a proteohy-

${ }^{7}$ Bot. GAZ. 18: 105. 1893. ${ }^{7}$ Bot. Gaz. 18: 105. 1893.
${ }^{8}$ Science (New York), 1892, 253. Fifth Report of the Storrs Agr. Exp. St3
tion, I892. I06. 
drolytic as well as a pectic enzyme. The enzymes of the pathogene bacteria are subjects of a great deal of study, and much has been written on them.

Zymogens ("mother of ferment") are known from the animals. They have been found in plants, such as Nepenthes, in resting wheat grains, in the irritable cells of Dionaea muscipula, and in others.

A discussion of the constitution of the enzymes, the many theories with reference to their mode of action, etc., forms the conclusion of Professor Green's solid work.-J. CHRISTIAN BAY.

\section{Equiseta in the carboniferous. ${ }^{9}$}

It is now about nine years since MM. Renault and Zeille ${ }^{10}$ published from the Commentry basin, upper coal measures, a description and figure of an Equisetum stem about $\mathrm{I} 22^{\mathrm{em}}$ long and 4 or $5^{\mathrm{cm}}$ wide, showing thirteen nodes which are provided with unquestionable toothed sheaths in the arrangement characteristic of Equisetum. This Equisetum Monyi constitutes perhaps the first really good evidence of the presence of the genus in the carboniferous, though a number of unsatisfactory species of Equisetites were published years ago by older authors. This evidence is now essentially corroborated by the description and illustration, by Mr. Kidston, of several fructifications which, although the under sides of the hexagonal sporangiferous shields with the sporangia cannot be seen, are so nearly identical in every character with the cones of Equisetum limosum $\mathrm{Sm}$. as to leave almost no room for doubt as to the existence of the actual genus as far back in geologi$\mathrm{cal}$ time as the carboniferous. The specimens are from the shale in the Barnsley thick coal, in the middle coal measures of Yorkshire, England.-DAvid WHiTE.

\section{The mechanics of growing plants.}

While Charles Darwin, Krabbe, Clark and others have brought to light many important facts bearing upon the work accomplished by plants in growth and movement, yet to Dr. Pfeffer must belong the credit of the formulation of the gen-

\footnotetext{
Robert Kidston; On the occurrence of the genus Equisetum ( $E$. Heming138-141. ${ }^{10}$ Comptes Rendus, 5 Ja 1885 . Études sur le terr. houill. Commentry.-Flore fossile 2 : 394. pl. $57 . f$. 7 . St. Etienne, 1890.
} 


\section{$2 \mathrm{BHL}$ Biodiversity Heritage Library}

Bay, J. Christian. 1894. "Vegetable Ferments." Botanical gazette 19(2), 68-71. https://doi.org/10.1086/327016.

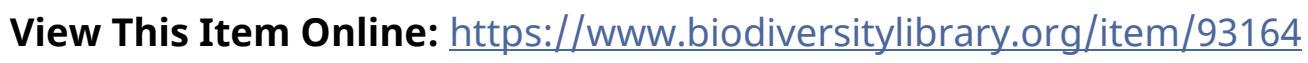

DOI: https://doi.org/10.1086/327016

Permalink: https://www.biodiversitylibrary.org/partpdf/222337

\section{Holding Institution}

Missouri Botanical Garden, Peter H. Raven Library

\section{Sponsored by}

Missouri Botanical Garden

\section{Copyright \& Reuse}

Copyright Status: Public domain. The BHL considers that this work is no longer under copyright protection.

This document was created from content at the Biodiversity Heritage Library, the world's largest open access digital library for biodiversity literature and archives. Visit BHL at https://www.biodiversitylibrary.org. 